Arch. Surg. 27 : 466-489, 1933.

4) Kewenter, Y.: Die Sesambeine des I Metatarsophalangeal-gelenks des Menschen: eine röntgenologische, und pathologischhistologische Studie, Acta orthop. scandinav. supp. 2, 1936.

5) Leonard, M. H. : The sesamoids of the great toe - The pedal polemic; report of 3 cases. Clin. Orthop. 16:295-301, 1960.

6) Meis, F. : U̇ber Osteochondropathie der Sesambeine des Grosszehengrundgelenks und ihre Beziehungen zur statischen Insuffizieng des Vorfusses. Arch. Orthop. UnfallChir. 26: 581-592, 1928.

7) Müller, W.: Malazie der Sesambeinknochen des I Metatsale, ein typisches Krankheitsbild, Beitr. Klin. Chir. 134 : 308-318, 1928.

8）奥山繁夫 その他：第 1 中足骨種子骨の分裂に ついて, 日整会誌. 31:79-86, 1958.

9）大戸輝也 その他：第 1 母趾種子骨の無腐性壊
死の 1 例, 整形外科. $15: 609-611,1964$.

10) Renander, A.: Two cases of typical osteochondropathy of the medial sesamoid bone of the first metatarsal, Acta Radiol. 2: 521526, 1924.

追加, 九大整形問 杉岡 洋一 種子骨の骨折の診断は分裂種子骨が高頻度に存在す るため，非常にむつかしいと思う。

経過中の化骨形成をみるか, 組織学的所見，また骨 折前に分裂像がないてとをレ線上証明するとと，によ り始めて診断可能と思われるが.

問国立小目病院整形外科 浦野 良明 種子骨骨折の彭断はむつかしいと思うが，仮骨形成 がある場合, 外傷歴およで局所所見がはっきりしてい る場合などに診断可能と思われる。

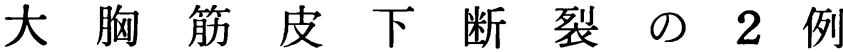

症 例報告亡文献的考察

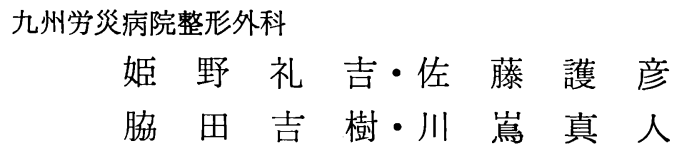

\section{Two Cases of Subcutaneous Rupture of the Pectoralis Major Muscle}

By

\author{
R. Himeno, M. Sato, Y. Wakita and M. Kawashima \\ Section of Orthopedic Surgery Kyushu Rosai Hospital
}

Rupture of the pectoralis major muscle is not common. This was first described in 1822 by Patissier. This was not yet described in Japanese literature. We would like to add our two cases to the previously reported thirty two cases and discuss etiology, location of rupture, treatment etc.

\section{はじめに}

大胸筋皮下断裂は文献的に，他の筋断裂と比較して まれな疾患である. 1822 年, Patissier の最初の報告
から 1973 年, Bragi Gudmundsson の報告までに, 32 症例が述べられているが，日本では報告例がない。 われわれの病院では, 大胸筋皮下断裂の 2 例を経験し たので, その症例を報告し, 受傷機転, 断裂部位, 治 
裺方針などについて検討してみる.

$$
\text { 1. 症例 }
$$

〔症例 1〕H.S. 23才, 男, 造型工。

昭和 47 年 12 月 15 日，仕事中ベルトコンベアに左 上肢を肩まで巻き込まれて受傷. 左前胸部痛, 左上肢 運動時の左腋窩部痛を主訴として来院. 左前胸部に擦 過創があり, 圧痛著明. 血腫と思われる軟い高度の腫 脹もある. 2 日後腫脹が減り, 擦過創から胸骨側上り に陥凹を生じ，局関節の内転により陥凹は明らかにな った．屃関節の内転筇群，内旋笳群に筋力低下が見ら れ，左大胸筋完全断裂と診断された。受傷後 1 週間目 に大胸筋縫合術を行った，大胸筋は，筋腹で完全断裂 しており，断端は鋸歯状の刻的目を有し，隆起してお り約 $6 \mathrm{~cm}$ の間隙があつた (図 1 )。両断端を引き寄 せ，筋縫合を行った（図 2 ). 術後 2 週間目に肩関節 の訓練を開始し， 3 週間目に退院した. 11力月経た現 在肩関節の機能障害はない。

〔症例 2〕T. T. 28才．とび職

昭和 48 年 1 月 9 日, 鉄骨を組み合せ作業中, 鉄骨と 鉄骨との間に, 右肩〜右腋窩部をはさまれ受傷. 診察 すると, 右前腋窩鲏璧に軟い腫瘤を認め, 波動を証明し た. 肩関節の可動制限があり, 局関節の内転筋群, 内 旋笳群, 後挙筋群および肘関節, 手関節の伸筋群, 手 指の筋力が著明に低下していた。. 上肢尺側の $\mathrm{C}_{6 \sim 8} \mathrm{~T}_{1}$ の領域に知覚鈍麻がみられた，右大胸筋完全断裂と診 断され, 右広背筋断裂, 右腕神経叢麻痺を合併してい た (図 3 ). 受傷後 3 週間目に, 大胸笳縫合術を行っ た. 右前胸部，鎖骨下より腋窩にかけて孤状の皮觜切 開を加えた。断裂した間隙には，血腫後囊胞が形成さ れ, 透明な液体が貯溜していた（図 4). 霬胞壁を切除 し，断端を縫合し，3 週間デソー包帯で固定した。術後 4 週目より右上肢の訓練を開始し，13週目に退院.9 力月経った現在, 右肩関節の機能障害はない（図 5 ).

\section{II. 考察}

\section{（1）受傷機転}

Pulaski \& Chandlee (1941) は大胸筋断裂の原因 を4つに分類している（表 1). われわれの 2 症例で は, 前者は, 過度の筋緊張之直達外力, 後者は直達外 力によるものと思われる.

(2) 大胸筋断裂部位 :

断裂部位を記載してある 26 例について，われわれ

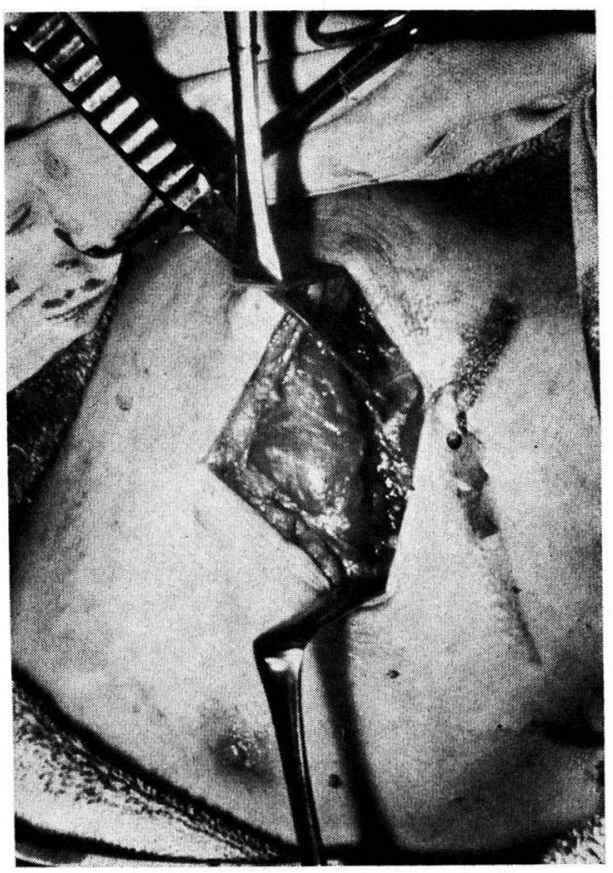

図 1 術前

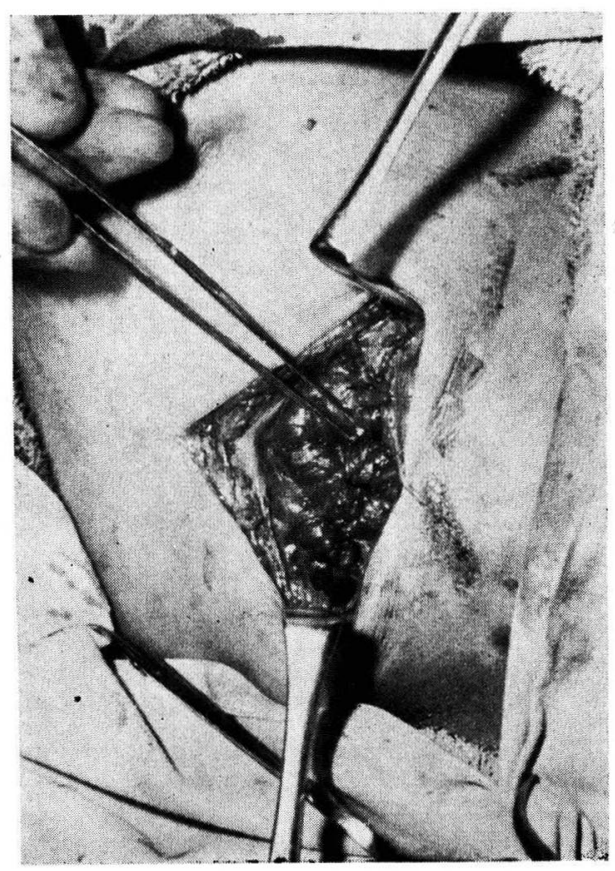

図2 術 後 


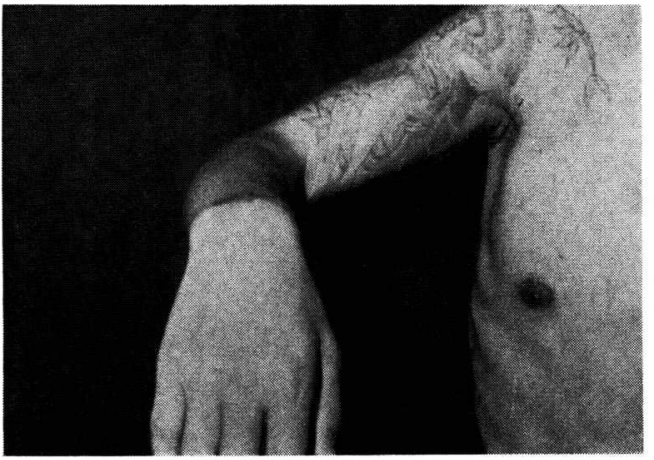

図 3

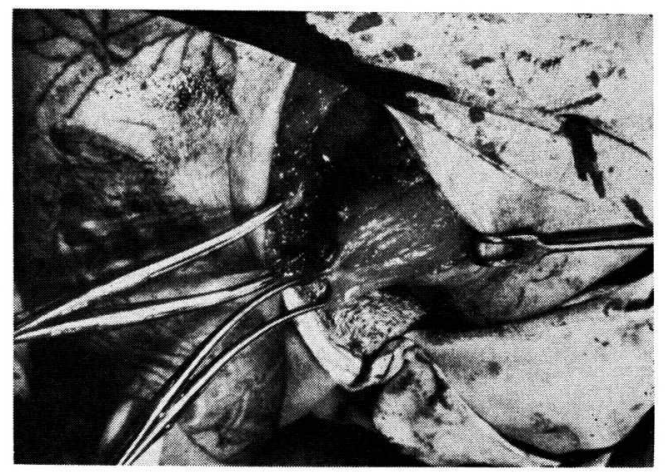

図4 術 前

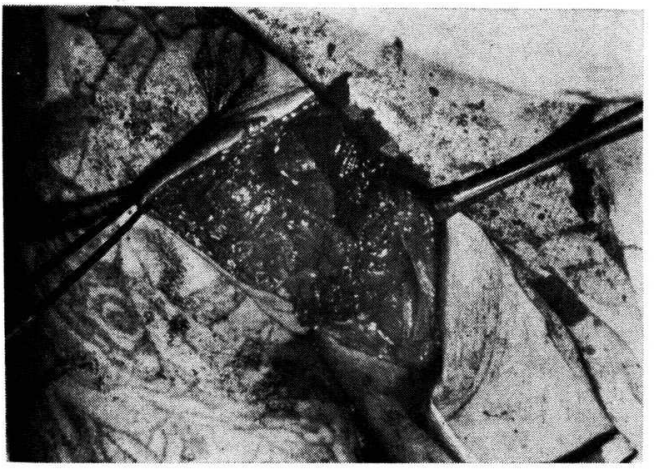

図 5 術 後
表 1 大胸筋断裂の原因

(Pulaski \& Chandlee (1941) による)

1) 過度の筋緊張

2) 直達外力

3) 過度の筋緊張と直達外力

4）老人性変化

表 2 26例中の大胸筋断裂部位

1) 腱付着部: 6 例

2) 筋 腹 部: 9 例

3) 筋腱移行部: 5 例

4) 筋 起 始 部：6 例

の行った統計によれば，表 2 の通りである.われわれ の症例は, 前者では筋腹部, 後者では筋腱移行部での 断裂であった。

（3）治療方針：

保存的治療か，あるいは観血的治療がよいかについ $\tau$, Park 弓大多数が，完全な機能回復を得るために は，早期の外科的修復が必要であり，保存的治療では 種々の機能障害が残ると述べている．われわれの症例 でも, 前者は受傷後 1 週目に, 後者は 3 週目に手術を 受けているが 2 例とも肩関節の機能障害は残存せず, 好結果を元ている。われわれも，早期の筋縫合の必要 性があると考えている。

\section{文献}

1) Bakalim, George : Acta. Orthoped. Scandinavica, 36:274-279, 1965.

2) Bragi, Gudmundsson: Acta Orthoped Scand. $44: 213-218,1973$.

3) McMaster, P. E. : J. B. J. S. 15: 705-722, 1933.

4) Park, J.Y. and Espiniella, J. L. : J. B. J. S.: vol 52-A, No. 3, 577-581, 1970.

5) Pulaski, E. J., and Chandlee, B. H. : Surgery, 10:309-312, 1941.

6) Schechter, L. R. and Gristina, A. G.: J. A. M. A., 188: 1009, 1964. 